\title{
Modernity, Communicative Action and Reconstruction of Rationality
}

\author{
Jason L. Powell \\ Faculty of Health \& Life Sciences, Coventry University, Priory Street, CV1 5FB \\ Coventry, United Kingdom \\ E-mail address: jasonpwll3@gmail.com \\ Associated with the Frankfurt School, Jurgen Habermas' rork focus the modern
}

\section{ABSTRACT} foundations of social theory and epistemology, the analysis of adva d capitali ac societies and democracy, the rule of law in a critical social-evolutionar antext, contemporary politics, particularly German politics. Habermas's theoretical syste 1 is devoted to ro aling the possibility of reason, emancipation, and rational-critical communicat $n$ latent in moden institutions and in the human capacity to deliberate and pursue rational intere Habermas $/ \mathrm{s}$ known for his work on the concept of modernity, particularly with respect to the dis ions of ra lonalization originally set forth by Max Weber. He has been influenced by Amemican pragmo action theory. This paper sets out to explore the problems and possibilities of com tive action and the reconstruction of rationality which Habermas claims was lost in postmodern $\mathrm{g}$ pre.

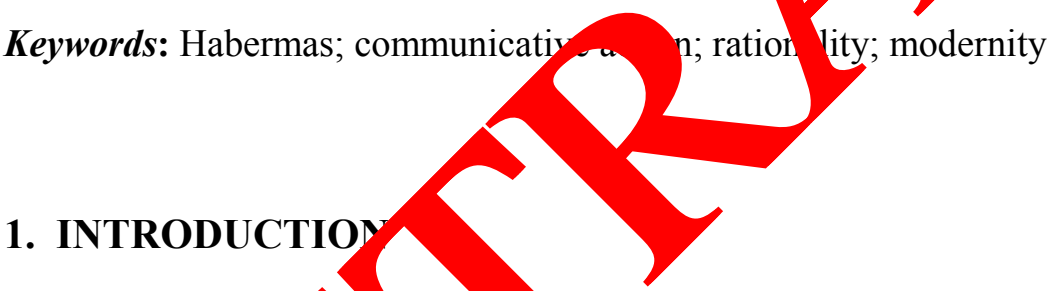

The philos pncal works Jygen Habermas occupy an unparalleled position in Western society. The 1 e Rick Roderick 1986) claims Habermas represents the most important attempt at re-constrac coulcal th ory out of the shadows of Marx. Coupled with this, Habermas uses Kant and Hege revita se Marxism by developing an emancipatory theory of society. In addit on, ording Delanty (2000) his relation to Adorno, Horkheimer, Benjamin and M se a Frankfur school is important in interpreting his modernist insights. Despite this, Delan zoou, laims Habermas is more affirmative and keen towards the classical philosop 1 tradition particularly the 'enlightenment'. For the past two decades in particular, Habermas as written on the enlightenment project in a reflexive manner: facing up to enlightenment thought and legacy via a systematic critical analysis of the present: its historiography, pathologies, and futurology. At the same time, there has been a huge escalation of neo-Nietzschean philosophers under the labels of 'postmodernist' and 'post-structuralist' who have castigated the enlightenment to the dustbin of the history of ideas, that its metanarratives of 'progress' and 'freedom' have failed and that western rationality is exhausted (Delanty, 2000).

Habermas (1992) claims that neo-Nietzschean critiques of enlightenment fail because they lose a sense of direction. In regard to Foucault (1977), Habermas (1992) accuses him of 
'cryptonormativity' and 'irrationality': the former applies because Foucault cannot explain the standards Habermas thinks must be pre-supposed in any condemnation of the present; the latter because of the appellation of Nietzsche's influence. The somewhat legendary albeit brief dispute between Habermas and Foucault turns on whether Foucault is understood to be criticising modernity from a pre-modern or postmodern view. Habermas is willing to defend his own reconstruction of the modern enlightenment tradition, against those critics of modernity of whom he considers to be anti-modern because of the reactionary implications of their views. As Habermas points out: 'The Young Conservatives recapitulate the basic experience of aesthetic modernity' $(1981,7)$.

The main assumption for Habermas (1992) is that the project of mode nity c redeemed. The diagnoses of Horkheimer, Adorno, Nietzsche, Heiddeger, Fouc and Derr are false. Habermas's task is to strengthen the 'project of modernity' by reconstru $\mathrm{g}$ it vis vis the 'theory of communication'. Hence, the massive task is to overco ne the pes ism of late modernity, the indulgence of his predecessors at Frankurt, Adorno d Hor eimer 949), by resolving the dilemmas of subject-centred reason in the paradigr of nunicat action.

The next section highlights the significance of communicat se action he mafestation of everyday existence in modern society.

\section{2. 'BUILDING BLOCK' OF MODERNISM: CO MMUNICATIVIACTION}

The theory of communication attempts to faci te a cont huity of language fused into the project of modernity. According to Ramussen (1) idinand De Saussure's (1959) distinction between diachronic and synch fundamental in unravelling Habermas' thought: diachronic historical-evolutionary $\mathrm{s}$ her as anderstanding language follows the model of the enlightenment. From this persp ctive, Aabermas' attempt to reconstitute the project of modernity through lay guas is consi tent with diachronic model of understanding language. Language is the vel for he most fandamental form of social action, namely his theory of communicative a n. enras, 81,44$)$ defines communicative action as:

'... that form of soci raction h ych the plans of action of different actors are coordinated through a exch of communicative acts, that is, through a use of language orientated toward aching un 'standing'.

Sociolo ically, abermas (1981) fuses micro and macro dimensions: he uses Mead and Durkheim as a retical ridge to develop communicative action. While Mead is important because symb qlly nediated interaction, Durkheim is important because of his analysis of th ' 'sac d' and p. ess of secularization of religion. Therefore, Habermas (1981 and 1992) see. cy momoe communication' framework as a new way of retrieving the project of moder Haocrmas wants to show how the transformation from traditional society to modernit, yolved a progressively secularization of normatively behaviour reconstructed through co /municative action. Drawing on his assessment of communicative competence of social actors, Habermas (1981) distinguishes between 'action orientated to success' and 'action orientated to understanding' and between the social and non-social contexts of action. Action orientated to success is measured via rules of rational choice; action orientated to understanding takes place through 'communicative action'. This manifestation of communicative action materialises by mutual and co-operative achievement of understanding amongst collective participants. 
Communicative action is linked to the reason embodied by universal pragmatics, since it is directed by search for intersubjective recognition of validity claims (truth, rightness and sincerity) although this may be only implicitly present in any case of actual social interaction. Communicative action is based on an analysis of the social use of language oriented to reaching understanding which focuses on the action co-ordinating effects of the validity claims offered in speech acts (Habermas, 1981). Communicative action is internally linked to communicative rationality which is a central plank for a critical theory. This involves an attempt to characterise universal features of communication in their structure and consolidation that remains open to empirical rationality and verification. Similarly, Roderick (1986) interprets communicative rationality as an attempt to identify empirically the historical development or ration y structures as well as problematizing further rationality to more modern spheres social life

Habermas' (1981) notion of Lebenswelt or 'lifeworld' must be introdyned à contexty marker to link action theory with rationalisation processes. This means y iderstandi vot ast how particular actions may be judged as rational but how rationalit otent in mo crnity embed particular actions and makes possible rational conduct o ev life. ábermas conceptualises the 'lifeworld' as the taken for granted univer of ever v ex stence. For Habermas (1981) the lifeworld is the saturation of commy al ve action radition and routinized way of doing acts. The lifeworld is a pre-interpre set o rms of he within which daily conduct materialises. In Habermas' view the concer for the of evolutionary development of society, culture and individual pers lality is the articy ation of the lifeworld that correlates with an internal system of language We can see therefore that the lifeworld forms the linguistic context for processes of commun tion. For labermas (1981) through the rationalization of the lifeworld social change-is said to o d cesses of rationalization within the lifeworld are said to occur through con action while irrational processes of change occur through strategic action. By ex end is Weber's theory of rationalisation, Habermas claims society can flourish alo lines of progressive differentiation and rationalisation. Habermas (1981, for the ec ectic theorist, draws on notions from Talcott Parsons of 'social system' to ify a it becom is more differentiated, the lifeworld becomes ever more rationalised. Th po the lifeworld and social system become ever more differentiated om each o but as they do each new system developed can further life possibilities ( $\mathrm{Ke}^{\mathrm{y}}$ ner, 89 ). The on-realisation of these possibilities leads to counteremancipation: the tang of of communicative imperatives by strategic imperatives via colonisation of ne lifeworld.

\section{3. 'IV T BLL UND RED CORNERS': LYOTARD V HABERMAS}

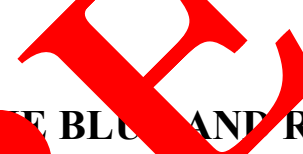

ho, theory of communicative action', a debate on postmo nism emerged in western social theory. The debate was instigated by Derrida, Baudrilla $d$ Lyotard on the tradition of the modern and calls for breaks within this tradition. For Lyotar (1984), Habermas' project of modernity has become obsolete and society had entered the 'postmodern condition'. Lyotard (1984) claims modernity could not think itself, get hold of itself intellectually, with distancing itself historically achieved implementations. For Lyotard (1984, 111):

'My argument is that the modern project [of realising universality] has not been abandoned or forgotten but destroyed, liquidated'.

Further, Lyotard (1984) is scathing of how Habermas will: 
'... use the term 'modern' to designate any science that legitimates itself with reference to a metadiscourse making an explicit appeal to some grand narrative, such as the dialectics of the Spirit, the hermeneutics of meaning, the emancipation of the rational'.

The very concept of 'postmodernism' is defined by Lyotard $(1984,55)$ as 'incredulous towards metanarratives' and asks 'where after the metanarratives can legitimacy reside'. For Lyotard (1984) what Habermas is offering one more metanarrative of 'communicative action' which is a generalist and abstractual narrative of emancipation. Lyotard (1984) is against the language games of metaphysics and philosophy of science. Lyotard (1984) calls for an 'irreducible plurality' of language games each with its own 'local' rules, legitim and practices. Postmodernism offers to move beyond Habermas' modernist narrative and is rap gaining currency throughout social and human science disciplines way into $41^{\text {st }}$ centu (Powell, 2001). There are several themes that are shared in postmode ana whi h consolidate Lyotard's (1984) interpretation.

First, there is distrust in the concept of absolute and objective 'Tr an is vied as contextual, situational, and conditional (Biggs and Powell, 2001) on mphi is placed on fragmentation rather than universalism, again pushing vay from general and encompassing toward the particular (Powell, 2001). Third oca wer is pl serred over the centralized power of the nation state, and the decentralizat or the ess democratization of power, is a pervasive theme of postmodern narrati es (Mestrovic, 4). Fourth, reality is simulated but is otherwise not a very meaningful co cept; reality conceived as a general and universal truth is profoundly doubted (Foucault, 77). Fifth, ve are seeing the rise and consolidation of consumer culture that tends to put ' $p$ ' $r$ ' in th hands of the consumers, but can also equally manipulate consumers thro marketmo roys and interpolating discourses of consumer freedom by dictating costs in gl bar $\rightarrow$ olace (Biggs and Powell, 2001).

Finally, diversity and difference is emph si ed al valued above commonality based on homogeneity (Powell, 2001). Post rn anal, is of culture is no longer a fringe perspective as it promotes strategies of in viduc sm and Nersity; and it is critical of strategies that devalue individuals because or that control access to knowledge, and that assault identity (Biggs an Powell, 01). It sees ethics as situational.

The response to the cor yal develo 1 of postmodernism has infuriated as many scholars as it has intoxicated. is no vrise to see Habermas' reaction in particular as very antagonistic of and to postmo gither individuals encounter a strategic choice either:

'hold fast to e inte ins of the Enlightenment or give up the project of modernity as lost' (Habermas, 1, 0 ).

Ly rdian postmode nism which omits: 'a mo Tity an ariance with itself of its rational content and its perspective on the future' (Haberm 1984, 36).

Habe, nas (1984) in 'Philosophical Discourses of Modernity' recognised that theories of postmodernism had their roots in irrational precursory influences such as Heidegger and Nietzsche. Habermas (1984) contends that modernity 'rebels' against tradition and has valorised highly charged aesthetic experiences of novelty, dynamism, singularity and intense presence. With increase innovation in technology and science, modernity embedded a sense of foundationalism and ontological security to society and the self in general. Further, Habermas claims that the project of modernity was 'unfinished' and contained unlimited capacity for emancipatory potential. Such potential draws on the specialization of culture for the enrichment 
of daily life and simultaneously the rational organisational of everyday life and experience. The project of modernity has unlimited potential to increase social rationality, justice and morality; this can be realised by cognitive progression and moral boundaries of rationality.

From Habermas' (1984) point of view the defence of the enlightenment is qualified. He gives sweeping castigation to the 'young conservatives' whom he accuses of setting up 'false programs of the negation of culture' which fail to realise positive contribution to project of modernity.

\section{PUTTING HABERMAS UNDER THE THEORETICAL MICROSCOPF
Habermas' (1981, 1984, and 1992) exhaustive, complex, and defonsi heoretic
arguments are very much open to scrutiny. Habermas' theoretical archri al Nikolas hm nn (1982) has dismissively claimed: \\ '... there are far too many grounds and arguments... when it ano en ver precisely determined in advance what is relevant and what is not ... cop unication $i$ actual fact, not lead to anything' (Luhmann quoted in Brand, 1990, 120}

In addition, Doorne (1985 cited in Brand, 1990) os that hos does not really distinguish between two contexts of analysis: firstly formal universal pragmatics; secondly, empirical research. Similarly, Brand (1990) rejects I bermas' position because of his hostility to empirical research and deduced logic. Coupled wi this, Ther orn (1986 cited in Roderick, 1986, 2-3) has castigated Habermas for deviating from of true science' by developing a 'speculative' epistemology which rejects $k$-Marxian concepts.

Ironically, there are two modernistic t se al grounds that Habermas fails to incorporate or appreciate in his analysis: gen ar and racial inequality. The former because Habermas' theorizing is built on a nceptio of the world in which, albeit essentialist characteristics but realities, 'Mle c ass' 'why 'e' 'males' dominate. The whole 'project of modernity' and associated cou hality and progress have historically sided with men over women (Star y and Pà an, 1991). The enlightenment philosophizing was a language based seein $\mathrm{w}$ in an in fior position to that of a man; a period of patriarchal domination. Whils anley Pateman (1991) do acknowledge that Habermas' notion of emancipation ic influential to Minists seeking a normative theory of consciousness and liberation, sh toes re rvejudgement on Habermas' theory of communicative action. They see it as gender $\mathrm{d}$ and $\mathrm{p}$ yetuates enlightenment tradition of male streaming mainstream analysi recon ting project of modernity.

Seco lly, to o pound the adverse androcentric effects of 'project of modernity', it can be le dxith an zcusation of eurocentricism. According to Gilroy (1992) European culture was ho geneous during and after the enlightenment. He claims social theory can no longer understan nd interpret the project of the enlightenment without understanding the periphery. For examp $c$, the legacies of slavery, colonialism and imperialism serves as reminders to the over-ambitiousness of Habermas's hopes and aspirations for social life.

In addition, the central tenets of the 'project of modernity' including rationality and progress for which Habermas (1981) attempts to formalise as practical achievements, should be put into a dark context. As the predecessors at Frankfurt school in 1949 saw, Adorno and Horkheimer and Zygmunt Bauman (1989) powerfully narrates, the Holocaust provides a devastating critique of enlightenment legacy and thought and highlights the slipping into a barbarism of Nietzchean nightmares. For example, on one level, Hitler's regime in Germany 
merely refined and perfected $19^{\text {th }}$ century techniques of social discipline. But, on yet another level, Hitler's regime was a deliberate throwback to an archaic 'society of blood', a society of savagery and a society with a lust for domination, control and power; a society which raises further questions to the enlightenment project. Coupled with this, there have been periodic episodes of inhumanity which have ranged from genocide in Rwanda in the 1970s onwards, mass genocide and 'ethnic cleansing' in former states of Yugoslavia in Kosova in 1999 as one stark example. The most spectacular recent example was the terrorist attacks on 'twin towers' in New York and subsequent 'war' in Afghanistan. It is very difficult to implement Habermas' (1984) universalized narratives of communicative action, with so many differences toneen states, cultures and ideologies. It seems it is very difficult to provide a modern olution a postmodern problem: for example, diversity of fundamentalist beliefs and cop ruent actio (postmodern), communicative action is very brittle in overcoming instabilities or ch belie (Habermas' modernism).

\section{CONCLUSION}

In conclusion, Habermas' work is a concern with rethic ing th 'adition of critical theory and German social philosophy. Rationality, freedom ar a ju ice are i st theoretical issues to be explored and debated, but for Habermas (1981) hey are practical asks that demand utter commitment and relentless achievement.

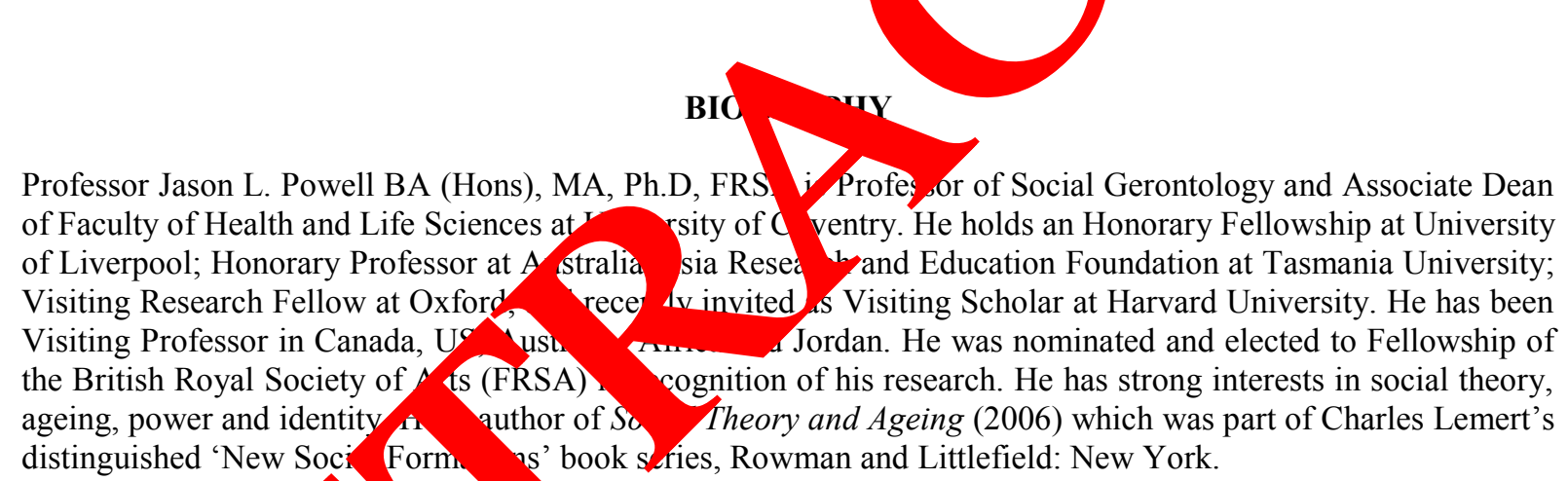

distinguished 'New Soci. Form, 's' book scries, Rowman and Littlefield: New York.

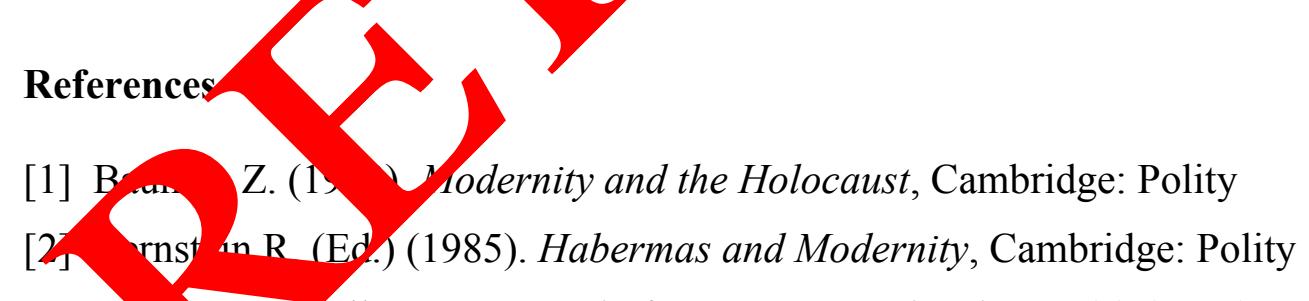

[3] Big. S., Powell J. L., Journal of Aging \& Social Policy 12(2) (2001) 93-111.

[4] Brand . (1990). The Force of Reason, London: Allen Unwin.

[5] Brenner W. H. (1989). Elements in Modern Philosophy, London: Prentice Hall

[6] Delanty G. (2000). Social Science, London: Routledge.

[7] Foucault M. (1977). Discipline and Punish, London: Tavistok.

[8] Gane M. (1981). Baudrillard, London: Routledge.

[9] Gilroy P. (1992). Black Atlantic, London: Hutchinson. 
[10] Habermas J. (1981). The Theory of Communicative Action, London: Beacon Press

[11] Habermas J. (1984). The Philosophical Discourse of Modernity, Cambridge: Polity

[12] Habermas J. (1992). Postmetaphysical Thinking, Cambridge: Polity.

[13] Horkheimer M., Adorno T. (1949). Dialectic of Enlightenment, Allen Unwin.

[14] Kellner D. (1989.) Critical Theory, Marxism, and Modernity, Cambridge: Polity.

[15] Levin D. (1993). (Ed.) Modernity and Hegemony of Vision, California: University of California Press.

[16] Lyotard J-F. (1984). The Postmodern Condition, Manchester: Manchester niversity Press.

[17] McCarthy T. (1978). The Critical Theory of Jurgen Habermas, Lor an: Hutch on.

[18] Mestrovic S. (1993). The Barbarian Temperament, London: R

[19] Powell J. L., Science Paper Publisher 4(2) (2001) 1-13.

[20] Rasmussen D. (1990). Reading Habermas, London: Bl ckh

[21] Roderick R. (1986). Habermas and the Foundation Critical ory, London: Macmillan.

[22] Stanley L., Pateman C. (1991). Feminist Interp tations and Political Theory, Cambridge: Polity.
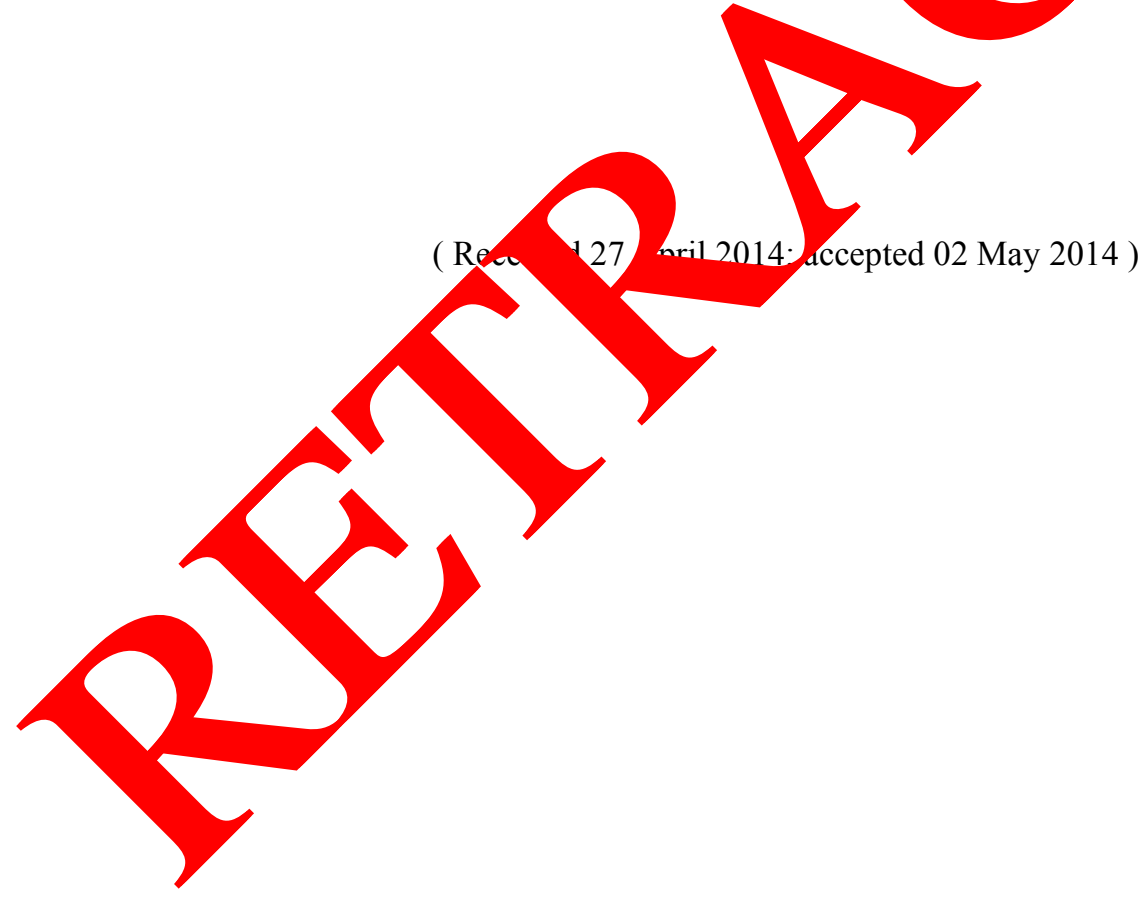